\title{
Mapping Challenges In Developing Sustainable Small And Medium Industries: Integrating Lean And Green Principles
}

\author{
Uly Amrina (iD, Akhmad Hidayatno (iD, Teuku Yuri M. Zagloel(D) \\ Universitas Indonesia (Indonesia) \\ uly.amrina@ui.ac.id,akhmad.hidayatno@ui.ac.id,yuri@ie.ui.ac.id
}

Received: November 2020

Accepted: February 2021

\begin{abstract}
:
Purpose: This study explores the complexity of developing a sustainable small and medium industry (SMI) through a conceptual model that integrates lean and green manufacturing principles.

Design/methodology/approach: This model includes a systems diagram that illustrates the structure of the interconnected variable and the interrelationships between goals, inputs, processes, and outputs required to achieve a system's goals by using both lean and green principles. The diagram uses causal loop diagram logic from systems thinking based on the literature review, multi-actor analysis, observations, and focus group discussions.
\end{abstract}

Findings: Combining the efficiency benefits from lean principles and better environmental effectiveness from green principles would help to achieve sustainability. A conceptual structural map could support the integration processes by illustrating the variables, multi-actors, and multi-indicators required to achieve sustainability.

Research limitations/implications: The conceptual model highlights the necessary linkage between lean and green practices that would help SMI researchers and decision-makers to navigate their activities in achieving sustainability.

Originality/value: There is currently little discussion at the SMI level from a multi-actor perspective. The systems diagram offers a comprehensive picture that is the basis for further discussion of the complexity of integrating lean and green principles.

Keywords: systems thinking, sustainability, lean, green, small and medium industry (SMI), cosmetics SMI

\section{To cite this article:}

Amrina, U., Hidayatno, A., \& Zagloel, T.Y.M. (2021). Mapping challenges in developing sustainable small and medium industries: Integrating lean and green principles. Journal of Industrial Engineering and Management, 14(2), 311-328. https://doi.org/10.3926/jiem.3401

\section{Introduction}

The small and medium industry (SMI) includes small and medium enterprises (SMEs) that are engaged in manufacturing processes. In some countries, SMIs play a vital, strategic role as the backbone of the country's 
economy (Kull, Kotlar \& Spring, 2018). They employ substantial manual labor and promote regional economic development. In Indonesia, SMIs comprise $90 \%$ of the industry (Hartanto \& Subagyo, 2018). Nonetheless, SMIs feature several weaknesses. Low productivity and unstable product quality (Asian Development Bank, 2014) make it difficult for SMIs to earn profit and survive in the long run (Gandhi, Thanki \& Thakkar, 2018; Thanki, Govindan \& Thakkar, 2016). Further, SMIs pay insufficient attention to the environmental impact of their processes and products (Muñoz-Pascual, Curado \& Galende, 2019). However, SMIs' informal management is one of their strengths, making such businesses highly flexible (Kull et al., 2018). Their use of simple technology requires them to employ workers with limited skills at the operational level, which is suitable for developing countries. SMIs also do not require significant capital. These factors contribute to the establishment of community-based businesses that provide appropriate jobs for the surrounding residents.

The cosmetics industry is Indonesia's second-highest SMI, according to the groupings in the 2015-2035 National Industrial Development Master Plan published by the Ministry of Industry (Pusat Komunikasi Publik Kementerian Perindustrian, 2015). In 2018, the number of cosmetics companies in Indonesia exceeded 760, of which 95\% were classified as belonging to the small and medium business sector (Kementerian Perindustrian, 2018). Accordingly, and owing to the primary use of chemicals in cosmetics products and residue from the production process, this paper conducts a case study of the cosmetics SMI. The cosmetics industry is locally supported by Indonesia's residents, making these companies more aware of social factors and their environmental impact.

To regulate the cosmetics industry's quality and performance, the Indonesian government implemented universal industry policies for all companies. The first policy mandated cosmetics SMIs to adhere to the good manufacturing practices (GMPs) established by The Medicine and Food Supervisory Agency (The Medicine and Food Supervisory Agency, 2019). GMPs aim to ensure that safe, high-quality cosmetics production and human resources employed by cosmetics SMIs have safe working conditions. The second policy concerns the environmental monitoring program conducted by the Minister of Environment. The Evaluation Programs for Company Performance in Environmental Management requires a quantitative report on SMI business processes, products, process residues, and environmental impact (Ministry of Environment, 2014). The government implemented this policy to overcome obstacles to improve industry competitiveness, given the limited availability of natural resources and dependence on imported raw materials, waste problems, and environmental issues (Khayam, 2019).

As decision-makers, SMI managers must navigate the challenges of multi-actors' conditions and achieve multi-dimensional sustainability indicators for their business strategy (Bai, Kusi-Sarpong, Badri Ahmadi \& Sarkis, 2019). Internally, they must overcome the manufacturing process and economic issues such as low productivity, low quality, and the limited skill of human resources. Externally, they must ensure that their production processes and products comply with regulations and do not damage the environment or society (Schwab, Gold, Kunz \& Reiner, 2017). Achieving manufacturing sustainability in the cosmetics SMI involves several complicated factors and actor/stakeholder interests.

SMI managers need to grasp the system's connecting components. However, they do not have a sufficiently broad perspective on the cosmetics SMI business. Their current view limits their decisions to the financial dimension and disregards other aspects (Eniola \& Entebang, 2016). Some focus on examining environmental performance (Yacob, Wong \& Khor, 2019), while others only focus on social performance (Su, Ji, Huang \& Chen, 2019). It is essential to expand their understanding of a multi-dimensional analysis using an integrative conceptual model. Research that discusses multi variables to support sustainable SMIs already exists (Dey, Yang, Malesios, De \& Evangelinos, 2019; Muñoz-Pascual et al., 2019); however, only a few studies have viewed SMI problems as dynamic and complex issues from a multi-actor perspective. Addressing such complexities requires a systemic approach. This study explores SMI managers' questions to develop sustainable cosmetics manufacturing by combining lean and green principles. The exploration uses a systematic approach represented as a systems diagram that might help them see the big picture. It includes determining the factors and variables involved and how they interact, the stakeholders' barriers and challenges, and how to achieve the goals together. 


\section{Literature Review}

\subsection{Importance of Lean and Green Principles for SMIs}

The requirement of SMIs to perform manufacturing processes at a competitive cost despite quality and resource constraints indicates the need for a lean manufacturing concept. The manufacturing industry has long applied lean principles to improve productivity by eliminating waste during production (Kropsu-Vehkapera \& Isoherranen, 2018). According to Hines and Rich (1997), there are seven types of waste produced in manufacturing operations: over-production, waiting, transportation, inappropriate processing, excessive inventory, unnecessary motion, and defects. Eliminating waste will enable shorter cycle times, better quality, and lower inventories (Kumar, Dhingra \& Singh, 2018). These efforts can increase the efficiency of the manufacturing process by saving production costs. In the end, the company's productivity and profitability will continuously grow. SMIs in various developing countries apply lean manufacturing principles to improve their performance (Panizzolo, Garengo, Sharma \& Gore, 2012). These improvements have succeeded in meeting customer requirements and increasing product demand. Unfortunately, they also trigger more and more goods to be produced and generate environmental pollution.

Destruction of the environment drives society to become critical and insist on environmentally safe products. Manufacturing managers are under tremendous pressure to create green production processes and products that do not endanger workers or society (Baines, Brown, Benedettini \& Ball, 2012). This condition requires a green manufacturing practice that effectively develops a production process with less environmental waste (Miller, Pawloski \& Standrigde, 2010). The terminology of waste in green practices is different from that of lean principles. According to Bergmiller (2006), environmental waste consists of toxic releases from chemical residues, emissions from energy use, solid waste, disposal from production lost, and total environmental impact along the product lifecycle. Eliminating environmental waste enables a manufacturer to pursue sustainability, which can be confirmed through its responsibility toward preserving life and social welfare (Reich-Weiser, Simon, Fleschutz, Yuan, Vijayaraghavan \& Onsrud, 2013). The SMI managers have to consider if its sustainability performance is aligned with its goal of achieving long-term benefits (Balachandran, Taticchi, Clarke-Sather, Hutchins, Zhang, Gershenson et al., 2011).

Although green practices promise a sustainable result, it is still unclear whether green practices can generate enhanced economic performance (Abualfaraa, Salonitis, Al-Ashaab \& Ala'raj, 2020). Some researchers argue that green practices might complicate the development of low-cost products and processes (Gupta, 2016; Wagner, Van Phu, Azomahou \& Wehrmeyer, 2002). Manufacturers including SMIs need to implement lean and green principles to balance current sustainability demands. The integration of the two concepts can mutually strengthen and compensate for their individual weaknesses.

\subsection{Sustainable Manufacturing Through the Integration of Lean and Green Principles}

Sustainable manufacturing requires indicators related to economic benefit, environmental soundness, and social responsibility (Singh, Modgil \& Tiwari, 2019; Zhou \& Liu, 2015). Here, the authors propose to achieve sustainability by integrating lean and green concepts by identifying the interconnecting conceptual relationships between the operational, economic, environmental, and social dimensions (Figure 1).

Figure 1 depicts a device that SMI managers can use to determine a sustainable manufacturing concept by combining lean and green variables. SMI managers also handle different interests in multi-actor conditions, directly influencing this conceptual map's development. Figure 2 shows the relationships between the actors involved in the cosmetics SMI. On the right are the production actors. On the left is the society that receives the production economy and environmental impacts. The community needs the government and academic institutions to regulate and help cosmetics SMIs to grow sustainably.

Figure 2 presents various ideas, goals, interests, causes, and the resources owned by each actor through multi-actor analysis (Halbe \& Pahl-Wostl, 2019). The managers can continue to develop multi-actor analysis tables comprising each actor's characteristics. These characteristics could be derived from a combination of literature reviews, field observations, interviews, and focus group discussions (FGDs). 


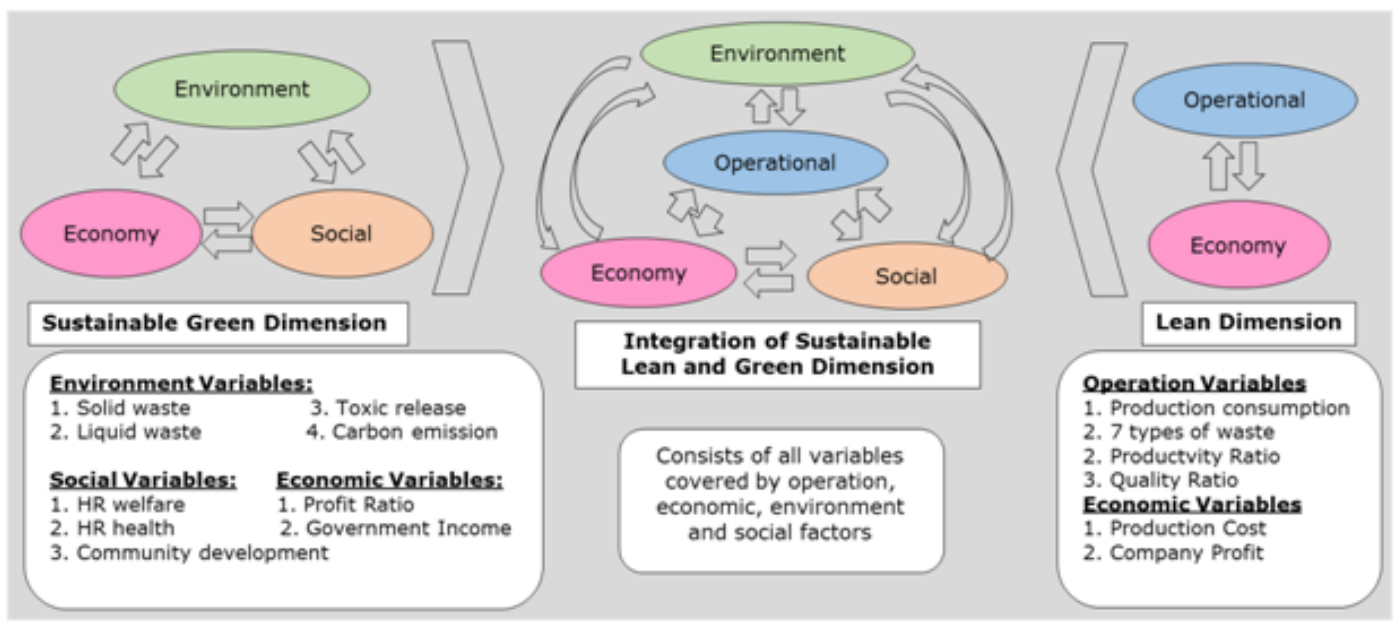

Figure 1. Integration of the lean and green concepts

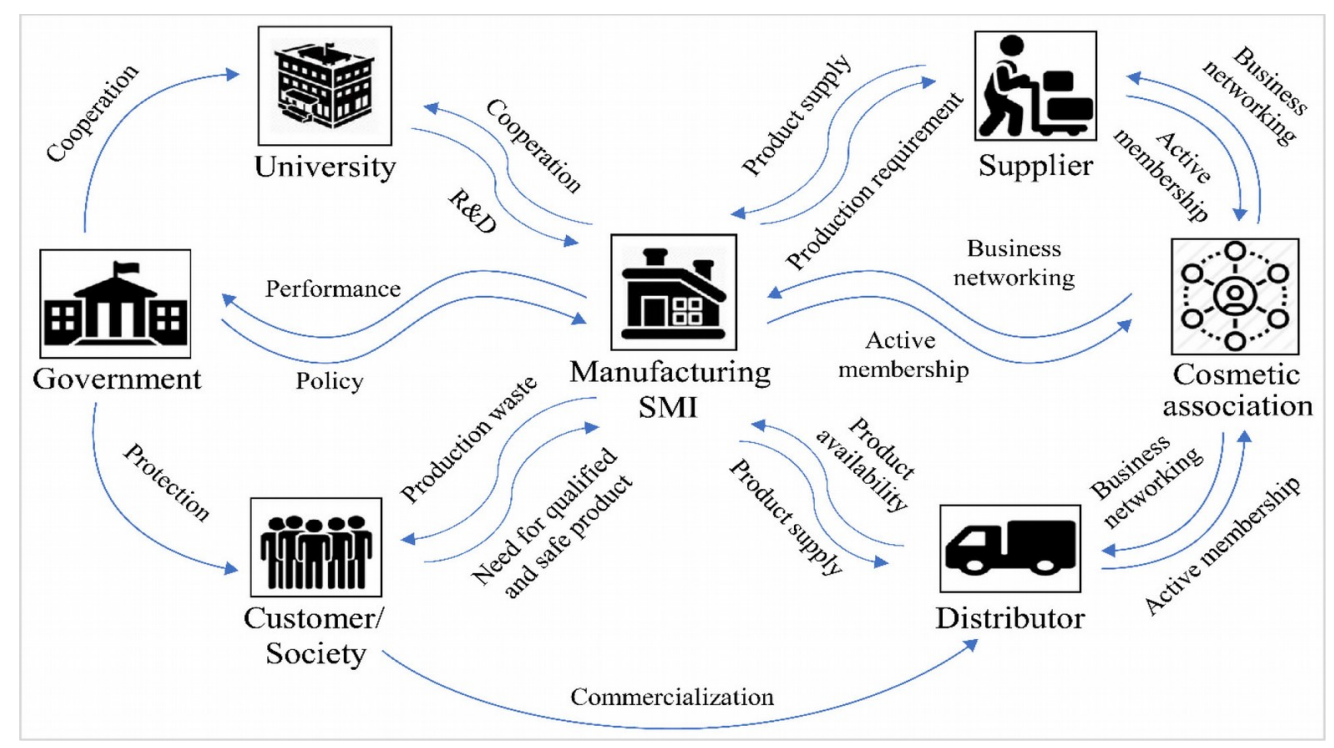

Figure 2. Dynamic relationship between cosmetics SMI actors

\subsection{Applying a Systems Thinking Approach to SMI's Dynamic Complexity}

Systems thinking is a conceptual methodology that recognizes dynamic complexity from various viewpoints corresponding to multiple actors with different interests (Sterman, 2010). This approach can improve decision-makers' competency in understanding a system and predicting behavioral patterns in the relationships between factors that influence it (Arnold \& Wade, 2015). Decision-makers use this approach to structuring a problem by looking at the big picture and progressively focusing on the details. Systems thinking is better for unraveling the complexity inherent in sustainability issues. It drives a mental model that clarifies ambiguities and hidden assumptions regarding complex problems (Van Mai \& To, 2015). Researchers have recommended using a systemic approach based on systems thinking to illustrate the interconnections between economic, social, and environmental sub-systems in developing a sustainable system (Hidayatno, Destyant \& Noor, 2019; RamosQuintana, Sotelo-Nava, Saldarriaga-Noreña \& Tovar-Sánchez, 2019). Essential to this approach is how decisionmakers uncover individual factors of each sub-system, explore how they interact causally, and decide which factors contribute to problem-solving.

Previous studies have examined the interrelationships between the variables in forming lean and green principles. Hallam and Contreras (2016) stated that the variables that influence lean and environmental waste have a dynamic interrelationship with increased corporate value. Although stated to have a dynamic relationship, the conceptual 
model did not form a causal relationship loop as characteristic of system dynamics. Gupta, Narayanamurthy and Acharya (2018) researched the relationship between lean and green principles in the Indian tire industry with systems dynamics methods. They proved that a lean manufacturing system would have a greener result. Nevertheless, further research regarding whether green manufacturing systems will impact lean results is required. In this paper, a causal loop diagram (CLD) shows the interrelationship connections between lean and green variables.

A CLD is a mapping tool to clarify the interconnections between the variables in a feedback structure. It uses arrows, symbols, text, and colors to show the cause and effect relationships between variables, accompanied by loop polarity, signified by a plus sign (“+”) or a minus sign ("-") (Kim, 1999). A positive sign (black arrow) indicates an increase or decrease in a cause that results in an increase or decrease in effect. A negative sign (red arrow) is used to denote an increase in a cause that leads to a decrease in effect and vice versa. A reinforcing loop (R) occurs if the circular relationship between variables forms a growth or decline feedback loop. Otherwise, a balancing loop (B) creates a continuous balancing feedback loop (Hidayatno, Rahman \& Muliadi, 2012).

Systems thinking introduces archetypes of basic patterns that show visible and hidden causal behaviors in a system (Kim \& Anderson, 1998). Archetypes are a reference for decision-makers to examine a system's characteristics and structure before formulating policies and strategies to avoid future recurrences of a problem (Prusty, Mohapatra \& Mukherjee, 2014). The concept avoids decision traps highlighted by the eight basic patterns or archetypes (Braun, 2002). For example, the "limit to success" pattern evinces rapid growth at the beginning of the solution but eventually slows down and decreases its success rate. The trap is to try harder; however, the better decision is to identify and reduce the barrier or growth. The decision-makers utilize these basic templates to trigger effective policy or strategy implementation (Vera, Nikulin, Lopez-Campos \& Gonzalez Ramirez, 2019).

\section{Research Methodology}

The methodology herein uses a combination of systems thinking approach with multi-actor analysis, as illustrated in Figure 3.

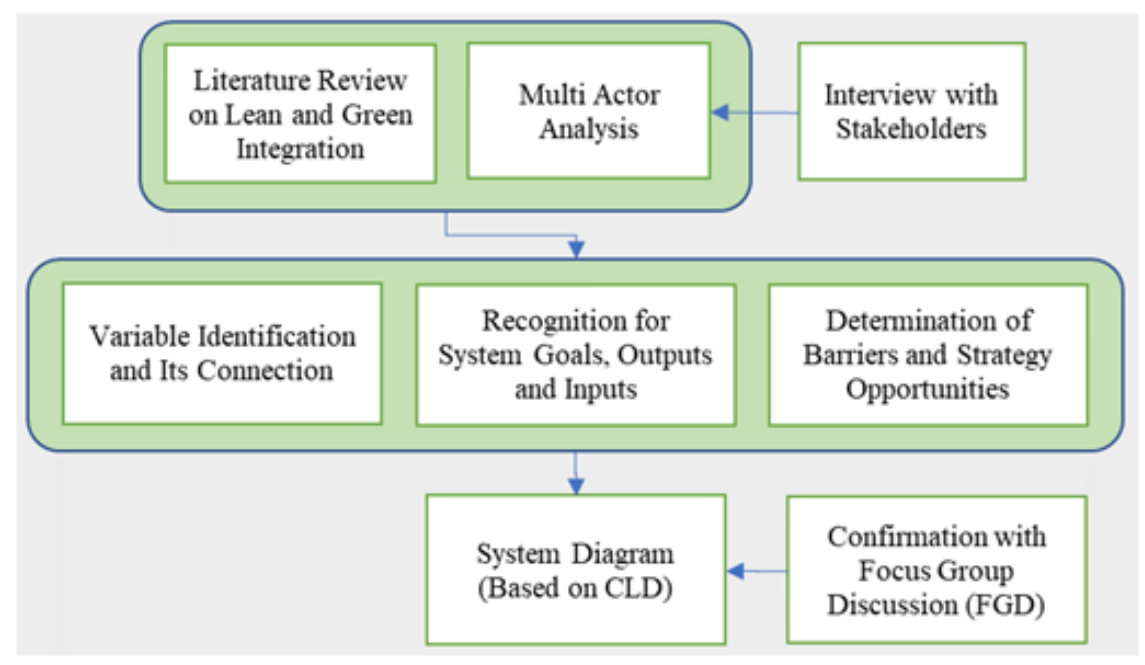

Figure 3. Steps in developing a conceptual model

The literature review starts the process by developing the conceptual model for integrating lean and green variables. This model is refined with the multi-actor analysis by detailing the system goals, inputs, variables, connections, outputs, and strategic alternatives. As part of the multi-actor analysis, interviews with stakeholders confirm and highlight the results of the literature review (Gubrium, Holstein, Marvasti \& McKinney, 2012). We interviewed seven stakeholders: two production managers from a cosmetics manufacturer, the owner of a cosmetics supplier, a marketing manager of a cosmetics distributor, two cosmetic experts from an industry association, and a cosmetics customer who lived in the manufacturer's area. We use these results to identify the obstacles for the cosmetics SMI and propose strategic alternatives to achieve sustainability. 
We then developed a system diagram — a conceptual illustration of the SMI managers' framework in managing complex systems (Figure 4).

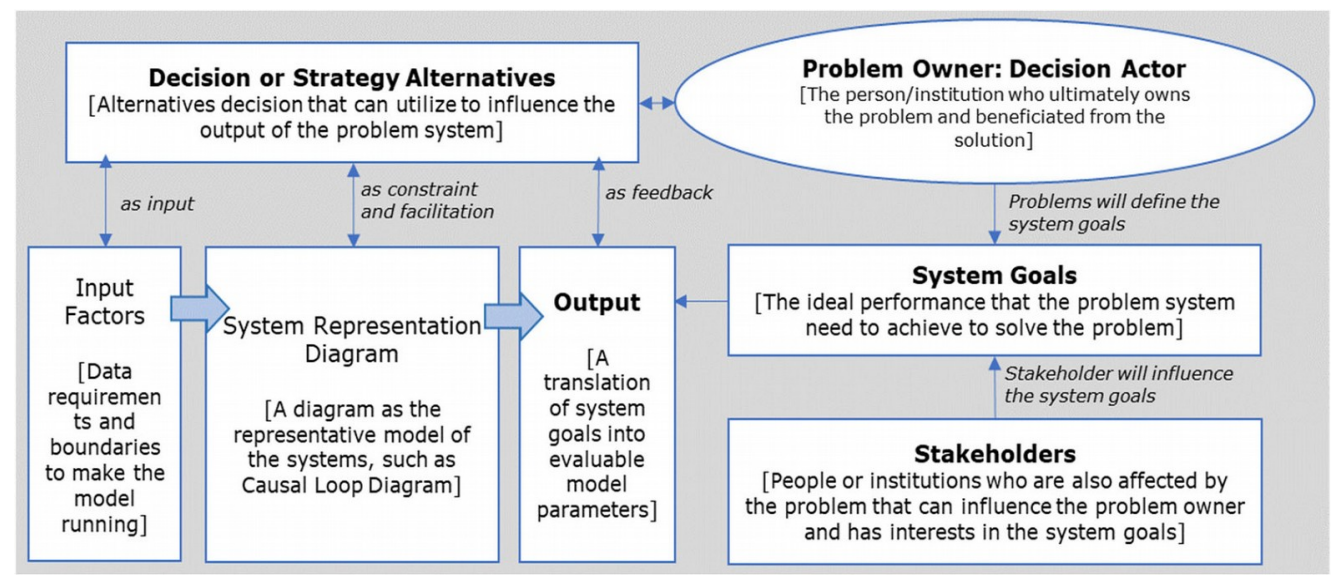

Figure 4. System diagram in input-process-output style

The process begins by identifying the problem owner and their goals. Multiple stakeholder interests influence the problem owner's goals. Then, we translate these goals into system outputs. The outputs are the model parameters generated by the processes coming from a structure of interrelated variables. The process requires inputs that constitute external factors and alternatives to policy variables. Moreover, the CLD represents the process area structure commonly found in the system dynamics approach.

Here, the researcher presented the initial CLD in an FGD to confirm its completeness and the interrelationships between individual factors and variables.

FGD is a qualitative research technique used to explore the perspectives, perceptions, and opinions regarding a concept or product from the experts' perspectives (Krueger, 2014). This technique enhances clarity and affords a deeper understanding of an objective via direct interaction with invited experts (Morgan, 2012). This research involved seven experts, comprising four SMI owner-directors and three operational/production managers with 20-30 years of experience, to verify the initial conceptual model. The FGD's structure included four steps (Demirbas, Holleville \& Bennett, 2018): a brief introduction, an explanation of the conceptual model, a core discussion, and confirmation of the discussion results. In the core discussion, the researchers confirmed the model variables' completeness, the causal relationships between variables, and the behavior of several variables over time.

\section{Results and Discussion}

\subsection{The Main Variables}

With the emergence of a sustainable manufacturer, several studies have proven the need to integrate lean and green manufacturing concepts (Amrina \& Zagloel, 2019). Aguado, Alvarez and Domingo (2013) examined variables that supported the creation of a sustainable lean production system, including material cost, selling price, profit, primary energy, and global warming potential (GWP). Manufacturers might obtain efficient material costs if they consider production and consumption, including material and energy consumption and material price. Hallam and Contreras (2016) determined the variables that support the integration of lean and green principles, including seven types of waste, the number of goods sold, production costs, revenue, company differentiation, employee satisfaction, green branding, and demand. They figured out that a company producing minimal waste during the manufacturing process would have higher productivity and profitability, which would promote company differentiation and increase employee satisfaction. Moreover, the company could increase demand. Reis, Kipper, Giraldo Velásquez, Hofmann, Frozza, Ocampo et al. (2018) testified that there were indicators to quantitatively measure the application of lean principles, such as the amount of waste generated, material efficiency, and total consumption of resources. A company can assess green practices through energy consumption, investment in environmental protection, employee health and safety, environmental risks, carbon dioxide $\left(\mathrm{CO}_{2}\right)$ emissions, and product image. 
This research collected additional variables from lean and green integration studies, including production planning, production amount, production emissions, ecosystem damage, human health, number of overtime hours, and incentives as additional income for human resources (Aguado et al., 2013; Bergmiller, 2006; Curran, 2006; Eaton, 2013; Grifell-Tatjé \& Lovell, 2014; Gupta et al., 2018; Karasan, Erdoğan \& Ilbahar, 2018; Wang, Subramanian, Gunasekaran, Abdulrahman \& Liu, 2015). The relationships between those variables indicated that implementing lean principles would improve green performance and practicing green concepts would influence lean results. Subsequently, we grouped the variables and their interconnections into four sub-systems: manufacturing operations as well as the economic, environmental, and social dimensions.

Table 1 lists the four sub-systems with 30 variables that form a sustainable cosmetics SMI. The manufacturing operation and economic sub-systems specify the productivity and profitability index values as output indicators. Both indicators are quantitative benchmarks that have been used as lean performance indicators in previous studies (Hallam \& Contreras, 2016; Reis et al., 2018). Economic, environmental, and social indicators represent green performance (Mittal, Sindhwani, Kalsariya, Salroo, Sangwan \& Singh, 2017; Wu \& Low, 2012). Environmental performance is assessed according to the amount of environmental pollution (Resta, Gaiardelli, Pinto \& Dotti, 2016); human health indicators measure social performance (Wang et al., 2015); and annual tax payments to the government estimate economic performance (Arif, Faraz \& Atika, 2019).

\begin{tabular}{|c|c|c|c|c|}
\hline Sub-System & No. & $\begin{array}{l}\text { Variables/ } \\
\text { Indicators }\end{array}$ & Description & Reference \\
\hline \multirow{16}{*}{$\begin{array}{l}\text { Manufacturing } \\
\text { Operations }\end{array}$} & 1 & Goods sold & Number of products sold & Hallam and Contreras (2016) \\
\hline & 2 & Sales price & Product sales price & Aguado et al. (2013); Reis et al. (2018) \\
\hline & 3 & $\begin{array}{l}\text { Production } \\
\text { planning }\end{array}$ & Planned level of production & $\begin{array}{l}\text { Karasan et al. (2018); Reis et al. } \\
\text { (2018) }\end{array}$ \\
\hline & 4 & Goods produced & Number of goods produced & Gupta et al. (2018); Wang et al. (2015) \\
\hline & 5 & Defective & Number of defective products & $\begin{array}{l}\text { Gupta et al. (2018); Hallam \& } \\
\text { Contreras (2016) }\end{array}$ \\
\hline & 6 & Rework & $\begin{array}{l}\text { Number of defective products } \\
\text { reworked }\end{array}$ & $\begin{array}{l}\text { Aguado et al. (2013); Karasan et al. } \\
\text { (2018) }\end{array}$ \\
\hline & 7 & $\begin{array}{l}\text { Catch-up } \\
\text { production }\end{array}$ & $\begin{array}{l}\text { Additional production to meet } \\
\text { demand }\end{array}$ & Aguado et al. (2013) \\
\hline & 8 & Inventory & $\begin{array}{l}\text { Producing, storing, or buying } \\
\text { unnecessary goods }\end{array}$ & $\begin{array}{l}\text { Gupta et al. (2018); Karasan et al. } \\
\text { (2018) }\end{array}$ \\
\hline & 9 & Over-production & $\begin{array}{l}\text { Producing more goods than customers } \\
\text { demand }\end{array}$ & Eaton (2013) \\
\hline & 10 & Production waste & $\begin{array}{l}\text { Amount of waste produced due to } \\
\text { defects, waiting, over-processing, } \\
\text { inventory, and over-production }\end{array}$ & $\begin{array}{l}\text { Gupta et al. (2018); Hallam \& } \\
\text { Contreras (2016) }\end{array}$ \\
\hline & 11 & $\begin{array}{l}\text { Production } \\
\text { consumption }\end{array}$ & $\begin{array}{l}\text { Number of production resources } \\
\text { required }\end{array}$ & Aguado et al. (2013); Reis et al. (2018) \\
\hline & 12 & Material price & Material purchase price & Aguado et al. (2013); Reis et al. (2018) \\
\hline & 13 & $\begin{array}{l}\text { Material } \\
\text { formulation }\end{array}$ & $\begin{array}{l}\text { Composition of water and additive } \\
\text { materials in a product }\end{array}$ & Aguado et al. (2013); Reis et al. (2018) \\
\hline & 14 & Production cost & $\begin{array}{l}\text { Number of expenses required to } \\
\text { produce one product }\end{array}$ & Hallam and Contreras (2016) \\
\hline & 15 & Revenue & Company income & Hallam and Contreras (2016) \\
\hline & 16 & $\begin{array}{l}\text { Productivity } \\
\text { index }\end{array}$ & $\begin{array}{l}\text { Comparison of revenue as an output } \\
\text { and production cost as an input }\end{array}$ & Grifell-Tatjé and Lovell (2014) \\
\hline
\end{tabular}




\begin{tabular}{|c|c|c|c|c|}
\hline Sub-System & No. & $\begin{array}{l}\text { Variables/ } \\
\text { Indicators }\end{array}$ & Description & Reference \\
\hline \multirow{5}{*}{ Economic } & 17 & $\begin{array}{l}\text { Changes in } \\
\text { production costs }\end{array}$ & $\begin{array}{l}\text { Changes in production costs due to } \\
\text { changes in material purchase prices }\end{array}$ & Grifell-Tatjé and Lovell (2014) \\
\hline & 18 & $\begin{array}{l}\text { Changes in } \\
\text { revenue }\end{array}$ & $\begin{array}{l}\text { Changes in revenue due to changes in } \\
\text { sales prices (after discounts) }\end{array}$ & Grifell-Tatjé and Lovell (2014) \\
\hline & 19 & $\begin{array}{l}\text { Price recovery } \\
\text { index }\end{array}$ & $\begin{array}{l}\text { Ability of changes in income to cover } \\
\text { changes in costs }\end{array}$ & Grifell-Tatjé and Lovell (2014) \\
\hline & 20 & Profitability index & $\begin{array}{l}\text { Comparison of price recovery index } \\
\text { and productivity index }\end{array}$ & Grifell-Tatjé and Lovell (2014) \\
\hline & 21 & Taxes paid & Taxes paid by the company & Arif et al. (2019) \\
\hline \multirow{4}{*}{ Environmental } & 22 & $\begin{array}{l}\text { Energy types and } \\
\text { amounts }\end{array}$ & $\begin{array}{l}\text { Types and amounts of energy } \\
\text { consumption for production activities }\end{array}$ & Aguado et al. (2013); Reis et al. (2018) \\
\hline & 23 & $\begin{array}{l}\text { Production } \\
\text { emissions }\end{array}$ & $\begin{array}{l}\text { Type and amounts of } \\
\text { residuals/emissions from the } \\
\text { production process }\end{array}$ & Reich-Weiser et al. (2013) \\
\hline & 24 & $\begin{array}{l}\text { Global Warming } \\
\text { Potential (GWP) }\end{array}$ & $\begin{array}{l}\text { Relative measure of greenhouse gases } \\
\left(\mathrm{CO}_{2} \text { and other gases }\right) \text { in the } \\
\text { atmosphere }\end{array}$ & Curran (2006) \\
\hline & 25 & $\begin{array}{l}\text { Damage to the } \\
\text { ecosystem }\end{array}$ & $\begin{array}{l}\text { Value of environmental quality as } \\
\text { measured by the damage to species or } \\
\text { ecosystems within an area for a year }\end{array}$ & Curran (2006) \\
\hline \multirow{5}{*}{ Social } & 26 & $\begin{array}{l}\text { People's } \\
\text { unhealthiness }\end{array}$ & $\begin{array}{l}\text { Quality of healthiness measured by the } \\
\text { years of human life lost from a person }\end{array}$ & Curran (2006) \\
\hline & 27 & $\begin{array}{l}\text { Socially } \\
\text { responsible } \\
\text { product image }\end{array}$ & $\begin{array}{l}\text { Societal perception of product image } \\
\text { that triggers purchase intention }\end{array}$ & Hallam and Contreras (2016) \\
\hline & 28 & Overtime hours & $\begin{array}{l}\text { Number of hours worked in addition } \\
\text { to regular working hours }\end{array}$ & Bergmiller (2006) \\
\hline & 29 & $\begin{array}{l}\text { Rewards/Incentiv } \\
\text { es }\end{array}$ & $\begin{array}{l}\text { Amount of benefits that employees of } \\
\text { the human resource department } \\
\text { receive as a bonus for increasing } \\
\text { profits }\end{array}$ & Bergmiller (2006) \\
\hline & 30 & $\begin{array}{l}\text { Human resources } \\
\text { additional income }\end{array}$ & $\begin{array}{l}\text { Number of added benefits that } \\
\text { employees of the human resource } \\
\text { department receive out of their regular } \\
\text { income }\end{array}$ & Bergmiller (2006) \\
\hline
\end{tabular}

Table 1. Main Variables in Sustainable Cosmetics SMI

The literature review indicates several obstacles in implementing lean and green principles in developing countries (Panwar, Jain \& Rathore, 2016). These barriers can be categorized into organizational, technical, and economic perspectives (Mittal, Sindhwani \& Kapur, 2016). Unsuccessful implementation has previously been attributed to insufficient experience and expertise, little involvement from top management, funding constraints, and inadequate support from the government (Cherrafi, Elfezazi, Garza-Reyes, Benhida \& Mokhlis, 2017; Nakano \& Kojima, 2017). These issues will be relevant to managers in determining the appropriate strategies for achieving sustainability.

\subsection{Multi-Actor Analysis}

Problem structuring in systems thinking requires multi-actor analysis to capture the issues and describe stakeholder interests. In this study, researchers conducted interviews and mapped the problem perceptions and objectives from seven actors' viewpoints concerned about the cosmetics SMI. 
Table 2 point out that all actors have the same direction of interest in developing a sustainable cosmetics industry. Cosmetic manufacturers, society, and the government are the three most significant actors in the cosmetics industry. Cosmetics manufacturers are interested in running production with high productivity and profitability and environmental and social responsibility. These interests are aligned with the community's wishes, cosmetics users, SMI workers, and the government as a regulator. However, four important actors have not played an optimum role. Suppliers and distributors do not explicitly express their concerns about social and environmental aspects because of their lack of awareness. However, they do not oppose them. Likewise, cosmetics associations and research and academic institutions have not been actively involved. The cosmetics SMI tends to be reluctant to join associations because it has not experienced membership benefits. Research and academic institutions have not yet bound themselves because of difficulties in exploring the cosmetics SMI's dynamic complexity without the industry's openness. This situation leads to an opportunity to apply several alternative strategies that actively embraces putting all actors together. The strategy must also consider the interactions between actors to avoid conflicts of interest.

\begin{tabular}{|c|c|c|c|c|c|c|}
\hline No. & Actor & Problem Perception & Objectives & Interest & $\begin{array}{l}\text { Cause and } \\
\text { Problems }\end{array}$ & Resources \\
\hline 1 & $\begin{array}{l}\text { Cosmetics } \\
\text { manufacturer } \\
(\mathrm{SMI})\end{array}$ & $\begin{array}{l}\text { Operating with low } \\
\text { productivity, high } \\
\text { production costs, and } \\
\text { being less concerned } \\
\text { about the } \\
\text { environmental impact }\end{array}$ & $\begin{array}{l}\text { To improve } \\
\text { productivity and } \\
\text { profitability as well } \\
\text { as environmental } \\
\text { and social } \\
\text { responsibility }\end{array}$ & $\begin{array}{l}\text { Sustainable } \\
\text { business } \\
\text { (people, profit, } \\
\text { planet) }\end{array}$ & $\begin{array}{l}\text { Inefficient use of } \\
\text { resources and } \\
\text { unidentified waste }\end{array}$ & $\begin{array}{l}\text { Production } \\
\text { capability, labor } \\
\text { employment, } \\
\text { product quality }\end{array}$ \\
\hline 2 & Supplier & $\begin{array}{l}\text { Increasing material } \\
\text { prices }\end{array}$ & $\begin{array}{l}\text { To fulfill the } \\
\text { demand from } \\
\text { cosmetics } \\
\text { manufacturing }\end{array}$ & $\begin{array}{l}\text { Material price } \\
\text { stability }\end{array}$ & $\begin{array}{l}\text { Inflation in } \\
\text { imported raw } \\
\text { materials }\end{array}$ & $\begin{array}{l}\text { Power to hold } \\
\text { specific material } \\
\text { subject to } \\
\text { inflation }\end{array}$ \\
\hline 3 & Distributor & $\begin{array}{l}\text { Prices of local } \\
\text { cosmetics are too } \\
\text { high, and they are } \\
\text { hard to sell }\end{array}$ & $\begin{array}{l}\text { To produce cheap } \\
\text { and good quality } \\
\text { products }\end{array}$ & $\begin{array}{l}\text { Profitable } \\
\text { business }\end{array}$ & $\begin{array}{l}\text { High prices but } \\
\text { under quality } \\
\text { product from local } \\
\text { manufacturer }\end{array}$ & $\begin{array}{l}\text { Power to move } \\
\text { to another } \\
\text { manufacturer }\end{array}$ \\
\hline 4 & $\begin{array}{l}\text { Cosmetics } \\
\text { Association }\end{array}$ & $\begin{array}{l}\text { Develop business } \\
\text { networking along the } \\
\text { supply chain }\end{array}$ & $\begin{array}{l}\text { To develop reliable } \\
\text { cooperation by } \\
\text { sharing } \\
\text { information }\end{array}$ & $\begin{array}{l}\text { Growing } \\
\text { together }\end{array}$ & $\begin{array}{l}\text { Low involvement } \\
\text { of SMI }\end{array}$ & $\begin{array}{l}\text { Provide business } \\
\text { networking and } \\
\text { information }\end{array}$ \\
\hline 5 & $\begin{array}{l}\text { Customer/ } \\
\text { Society }\end{array}$ & $\begin{array}{l}\text { Unwanted side effects } \\
\text { from product use and } \\
\text { the pollution } \\
\text { generated by } \\
\text { cosmetics } \\
\text { manufacturers }\end{array}$ & $\begin{array}{l}\text { To buy a certified } \\
\text { product and live in } \\
\text { a healthy } \\
\text { environment }\end{array}$ & $\begin{array}{l}\text { Safe product, } \\
\text { safe living }\end{array}$ & $\begin{array}{l}\text { Use of hazardous } \\
\text { chemicals }\end{array}$ & $\begin{array}{l}\text { Ability to refuse } \\
\text { the } \\
\text { establishment of } \\
\text { certain cosmetics } \\
\text { SMIs }\end{array}$ \\
\hline 6 & Government & $\begin{array}{l}\text { SMI does not follow } \\
\text { governmental } \\
\text { regulations and } \\
\text { contributes little tax } \\
\text { income }\end{array}$ & $\begin{array}{l}\text { To monitor and } \\
\text { evaluate the } \\
\text { effectiveness of } \\
\text { regulations }\end{array}$ & $\begin{array}{l}\text { More jobs } \\
\text { offered by the } \\
\text { developed } \\
\text { cosmetics } \\
\text { industry and } \\
\text { increased tax } \\
\text { income }\end{array}$ & $\begin{array}{l}\text { Lack of } \\
\text { knowledge, } \\
\text { technology, and } \\
\text { capital }\end{array}$ & $\begin{array}{l}\text { Power to } \\
\text { regulate and the } \\
\text { capability to } \\
\text { supply subsidies }\end{array}$ \\
\hline 7 & $\begin{array}{l}\text { Research and } \\
\text { Academic } \\
\text { Institutions }\end{array}$ & $\begin{array}{l}\text { Less involved in } \\
\text { developing the } \\
\text { cosmetics SMI } \\
\text { business }\end{array}$ & $\begin{array}{l}\text { To expand } \\
\text { knowledge, } \\
\text { especially in } \\
\text { developing SMIs }\end{array}$ & $\begin{array}{l}\text { Collaborative } \\
\text { research }\end{array}$ & $\begin{array}{l}\text { Complexity of } \\
\text { SMIs' problems } \\
\text { and a lack of } \\
\text { research funding }\end{array}$ & $\begin{array}{l}\text { Knowledge, } \\
\text { technology }\end{array}$ \\
\hline
\end{tabular}

Table 2. Multi-Actor Analysis of Cosmetics Industry SMI Processes 
Actor analysis helps decision-makers understand problems in a system by identifying the variables and factors concerned and determining future policy scenarios (Hermans \& Cunningham, 2013). Based on Table 2, the variables defined are production costs, production waste, product quality, production residue, healthy environment, company revenue, and the amount of taxes paid by the company. These variables are consistent with Table 1 . The actor analysis discovered external factors, namely, material price increases by suppliers, customer demand, and government subsidies for the cosmetics SMI. The analysis also discovered that policy variables include controlling the defect ratio, material formulations, sufficient wastewater treatment tank capacity, and sales price. These external factors and policy variables become the inputs for the next stage of the process.

\subsection{Model Conceptualization}

\subsubsection{System Representation Diagram}

The researchers assembled five quantitative outputs to describe the goals referenced by the literature review and actor analysis. They are the productivity index, profitability index, the amount of taxes paid, the damage level to the ecosystem, and people's unhealthiness. Some variables that will generate these outputs are interconnected. Some of these interconnections create loops that return to their original variables. These loops create non-linear results that behave differently from linear results and act as early signs of systemic behavior.

The CLD highlights five reinforcing loops (R) and two balancing loops (B) (Figure 5). They configure the four main components of sustainable cosmetics SMI: just-in-time (JIT) production loops (R1-B1-R2), waste elimination process loops (R2-B1-R3), economic excellence triggered by productivity achievement loops (R1-B1-R2-R3-B2), and lean and green manufacturing through company materials and energy policy loops (R1-B1-R2-R3-B2-R4-R5).

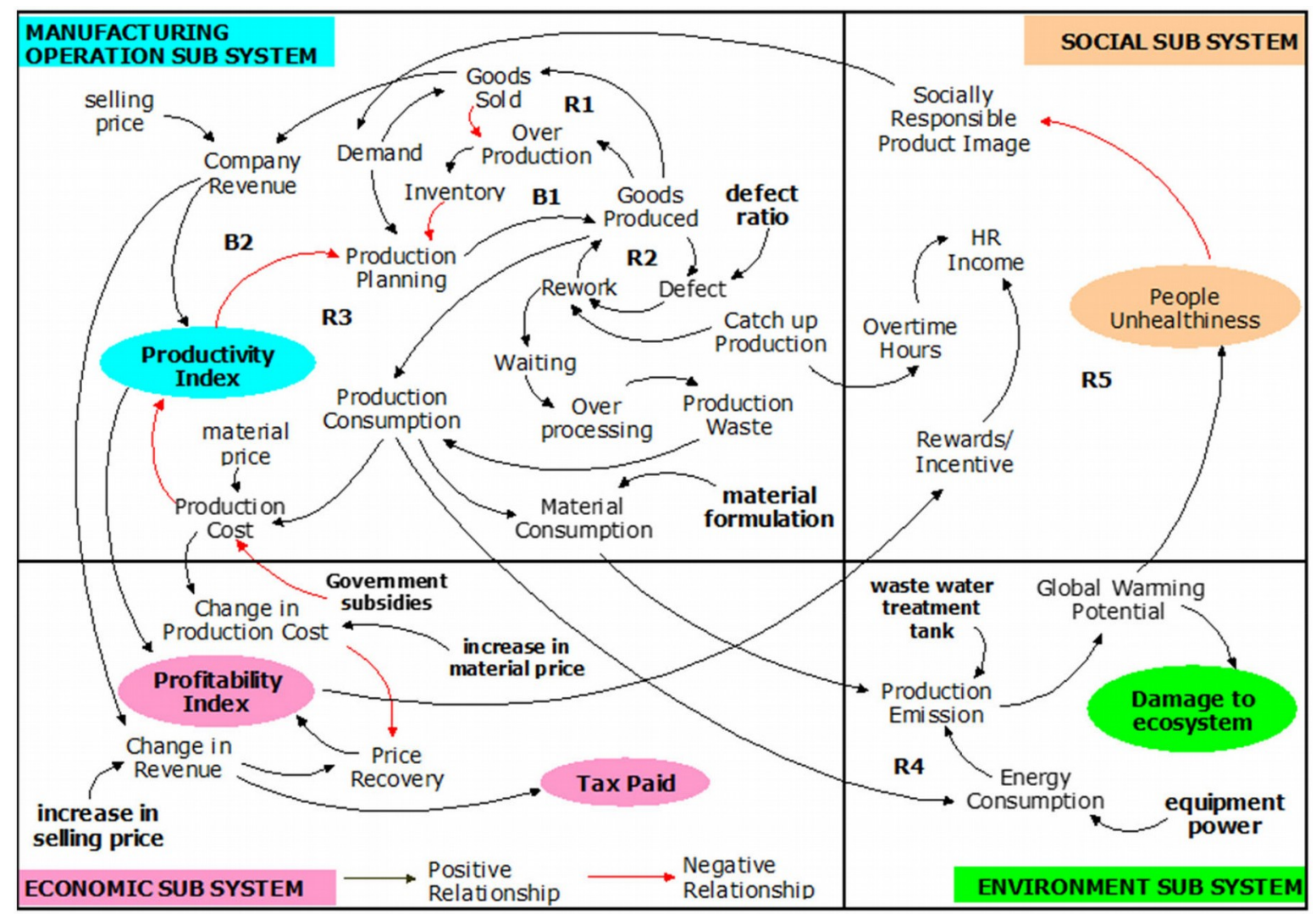

Figure 5. Conceptual models for sustainable cosmetics SMIs with causal loop diagrams (CLDs)

\subsubsection{JIT Production Loops}

These loops visualize the interconnections between production planning, production quality, production results, and the number of products sold, shown by two reinforcing loops (R1 and R2) and one balancing loop (B1). The 
number of goods produced results from production planning and reworked products. Over- or under-production will occur if the managers miscalculate during production planning. This condition will affect the company's inventory and the next period's production planning. For the JIT production principle, producing excess or too few goods increase the negative impact. Over-production decreases the quality of the goods and complicates warehouse arrangements. However, a production shortage will increase ordering costs for the next period of production planning. Managers should decide the correct production planning calculation considering demand, inventory price, productivity level, and defect ratio.

\subsubsection{Waste Elimination Process Loops}

These loops illustrate waste elimination variables' contribution to the production-consumption numbers and productivity index as manufacturing output. The interconnection was created by two reinforcing loops (R2 and R3) and two balancing loops (B1 and B2). The production waste variables involved in these loops include defects, over-production, inventory, waiting, and over-processing. The defect rate triggers loop R2, which influences other types of waste. Equipment reliability and human resource capability affect the defect ratio. Managers can implement lean and green improvement strategies to reduce the defect ratio and increase productivity by utilizing strategy alternatives.

\subsubsection{Productivity Loops to Improve Profitability}

The causal relationships formed by JIT production and waste elimination loops highlight productivity loops in the manufacturing sub-system. These loops cover the interconnections between three reinforcing loops (R1, R2, and R3) and two balancing loops (B1 and B2). These loops support the economic sub-system by achieving profitability index and tax payments. An increase in industrial output contributes to additional government tax income. The managers can consider sales price value as policy variables in these loops. Its ability to maintain sales prices and increase profits is its competitive advantage in the market. Cosmetics SMIs can achieve this condition by minimizing production costs. The SMI can utilize government subsidies to support lean and green improvement activities to reduce manufacturing costs.

\subsubsection{Lean and Green Manufacturing Loops}

Five reinforcing loops (R1, R2, R3, R4, and R5) and two balancing loops (B1 and B2) form the interrelationships between the manufacturing, economic, environmental, and social sub-systems. Loop R4 shows that the energy consumption variable increases production emissions, which increases the GWP in the long run. Simultaneously, loop R5 emphasizes material consumption as a variable causing water and soil pollution and potentially increasing GWP/ $\mathrm{CO}_{2}$. The GWP affects the human health level of society and then lowers the product image. This condition causes a decrease in demand because of the loss of public desire to buy these products.

The managers can take some policy variables in line with lean and green manufacturing activities. Those policies are related to the material formulation, selection of production equipment power types, and wastewater-treatment-tank capacity determination. At the same time, other policy variables are defect ratio and sales price. Reducing the defect rate minimizes the waste generated by waiting, over-processing, over-production, and inventory. This policy can succeed in waste minimization loops. Correspondingly, managers can position an optimal sales price to increase revenue but not to decrease customer demand. This scenario can strengthen economic excellence loops. Managers might combine the policy variables scenario to implement alternative strategies in the system diagram.

Based on the causal relationship between factors and variables in the four loops, we identified the archetype. The behavior interconnection between factors and variables expressed the "growth and under-investment archetype", as shown in Figure 6. A cosmetics SMI develops sustainable business to reinforce customer demand and encourage the SMI's revenue. However, the increase in demand results in a decrease in product quality performance and causes pollution. The quality and environmental performance of the SMI's behavior limits its development. Quality and environmental issues cause customers reluctant to buy SMI products that cause decreased demand. The SMI must undertake an investment support strategy to improve performance. That strategy will strengthen its resource capability including people's ability, equipment and facilities, and technology in the long run. 


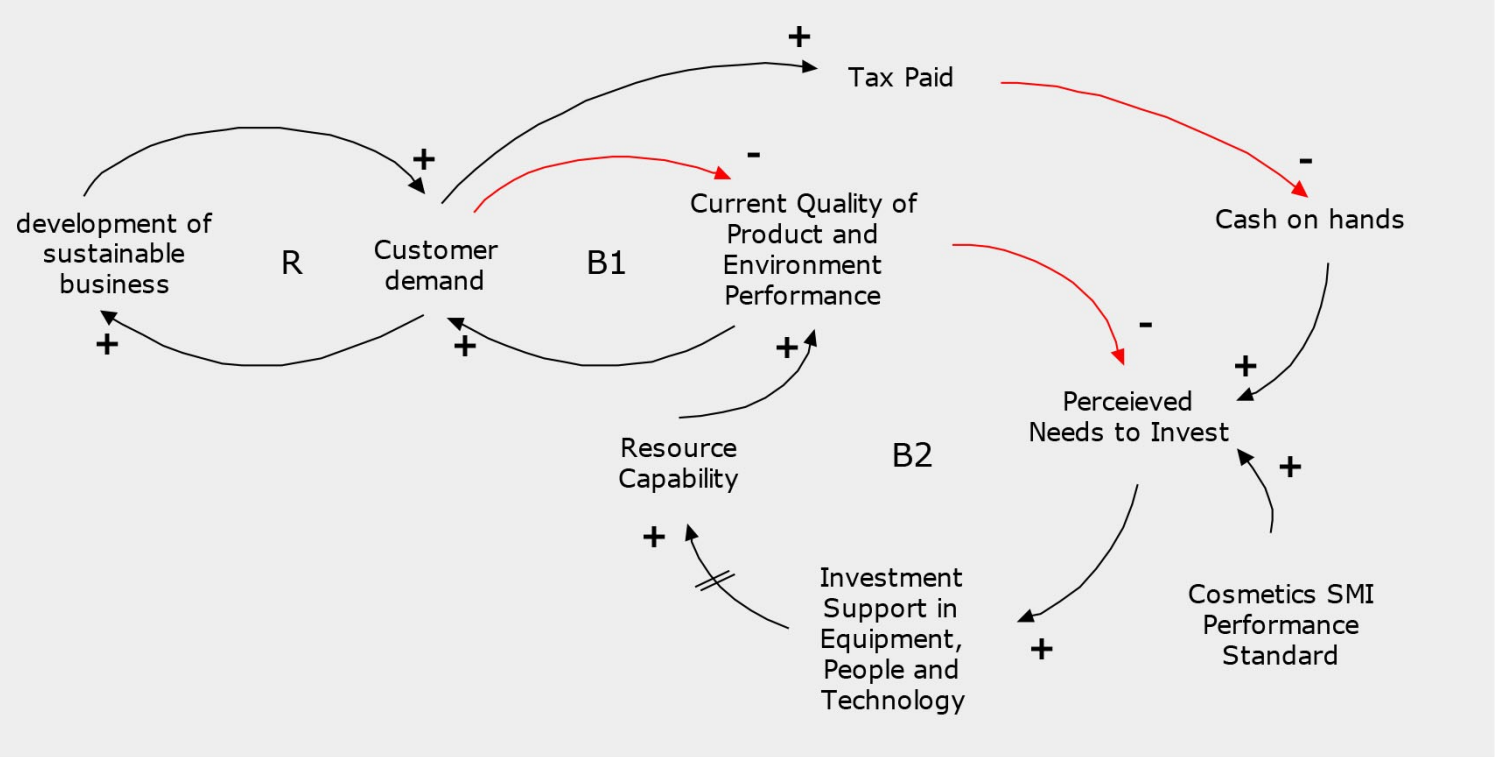

Figure 6. CLD of SMI's growth and under-investment archetype

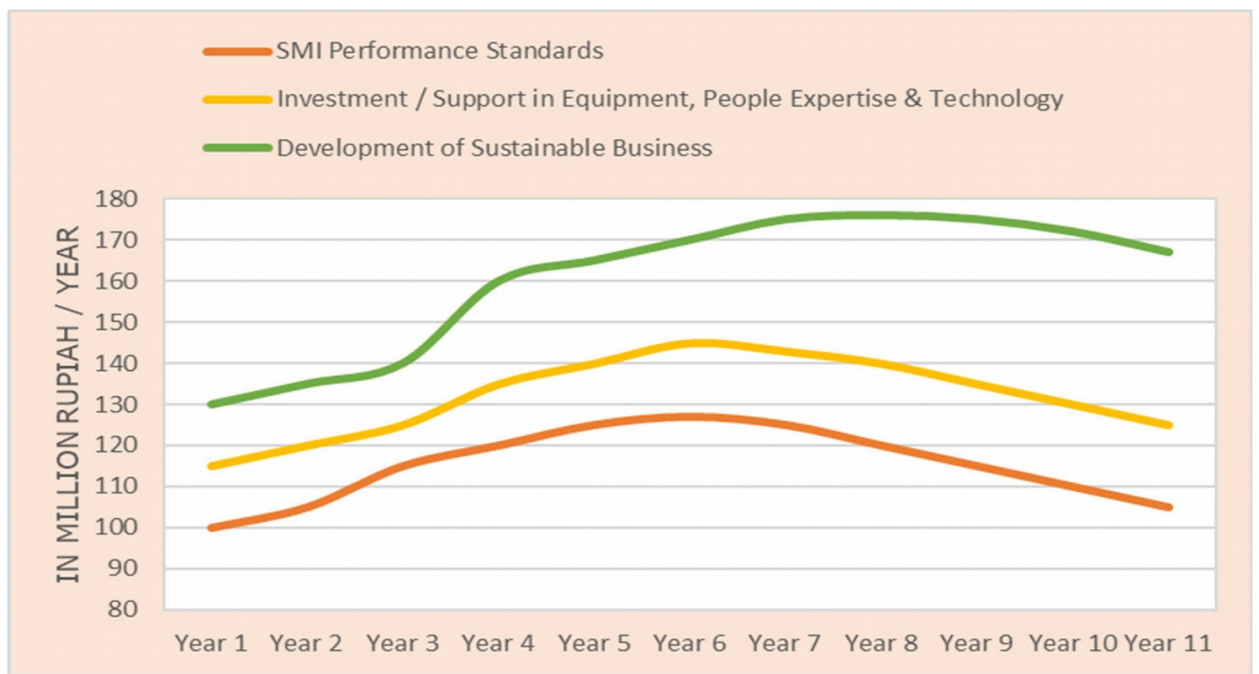

Figure 7. Behavior over time of SMI's growth and under-investment (in years)-illustrative

Figure 7 illustrates the predicted behavior of the growth and under-investment patterns over time. An SMI business will expand toward sustainability if it manages investment supports continuously. However, this trend will decrease when such support decreases. These conditions can reduce performance standards because of the increased difficulty in achieving the standards. The managers must find a proper strategy to enhance the SMI business' sustainable development.

The managers can establish investment priority plans according to improvement activities to achieve sustainable business. However, the SMI has limited capital so that investment support might collaborate with other stakeholders. Braun (2002) prescribed several actions that managers can take to avoid under-investment, such as learning the interrelationships pattern between performance indicators and resource availability and determining the right time and amount of additional investment. The managers must implement improvement activities that can shorten the delay between further investment and performance degradation. They must have proper investment signals driven from external needs, such as customers or the government and not just past performance. 


\subsubsection{Recommended Action}

The researchers confirmed the CLD and predicted behavioral patterns utilizing an FGD attended by seven cosmetics stakeholders. The FGD developed alternative strategies to achieve sustainable cosmetics SMIs. First, the strategic opportunities must consider how to minimize the five types of waste—defects, waiting, over-processing, over-production, and inventory — as the main variables in lean and green loops. Second, the strategy must also support policy variables such as material formulation, low energy equipment, and wastewater treatment tank development. Third, the strategic alternatives should overcome the barriers of the SMI regarding organizational perspective, technical capabilities, and financial strength. Thus, the alternative decision strategies discussed in the FGD as final parts are as follows:

1. Create opportunities for joint $R \& D$ with research and academic institutions since these actors have the competence to make process improvements and product innovations. SMIs need this collaboration, given their limited resources. SMIs can minimize rework and production catch-up activities to reduce production-consumption and costs and simultaneously innovate more environmentally friendly materials formulations, low power equipment, and appropriate wastewater treatment design. These activities reduce potential emissions.

2. Collaborate with raw material suppliers to ensure the continuity of supply for production needs. With materials formulation innovations through joint research, SMIs must ensure that suppliers can provide newly developed material formulations at competitive prices.

3. Propose government subsidies for reducing manufacturing costs. An SMI can demonstrate its current business contribution and how its prospects might increase government tax revenues. Subsequently, it can clearly outline its need for government subsidies for process improvement and product innovation to satisfy government regulations.

4. Develop a coordinating mechanism for all entities involved in the cosmetics business supply chain to propose government tariff discounts on imported raw materials. Cosmetics SMEs can leverage the power of cosmetics associations to launch this fourth strategy.

\subsubsection{Systems Diagram as Model Conceptualization}

Researchers conceptualized the understanding, actor analysis, opportunities and limitations, problem purpose, model output requirements, and processes to produce the system diagram.

In Figure 8, the problem-owners are managers of the cosmetics business. The managers face productivity and quality instability issues that reduce profits and government and community requirements to produce low pollution levels. Those problems drive the goal that influenced seven stakeholders with various interests that also affect achieving a sustainable cosmetics SMI. This goal is translated to process output indicators based on the literature review and multi-actor analysis. The CLD models the causal relationships between 30 lean and green variables from Table 1 to generate the output indicators. Finally, the system diagram recommends four alternative strategies from FGD results that influenced the system's input, processes, and output to achieve the goal.

Figure 8 shows that the application of the proposed strategies will affect the state of the system. The implementation of these strategies can increase the value of the system's output performance. However, their realization depends on the current system model's dynamic relationship, which can be either a stimulus or a constraint. It will be hard to achieve effectiveness in implementing the strategy if there are conflicts of interest between actors. For example, joint R\&D's strategy with research or academic institutions to improve products and processes will experience difficulties if companies do not disclose their policies and the data related to resource consumption. Companies will also find it challenging to apply for government subsidies if they do not collaborate with other stakeholders to perform their sustainability indicators. The systems diagram supports SMI managers comprehensively, examining the relationship between input factors, variables, strategy selection, and output generated from a complex system. This diagram helps them to observe the series of difficulties confronted when a problem occurs and how they can solve it. 


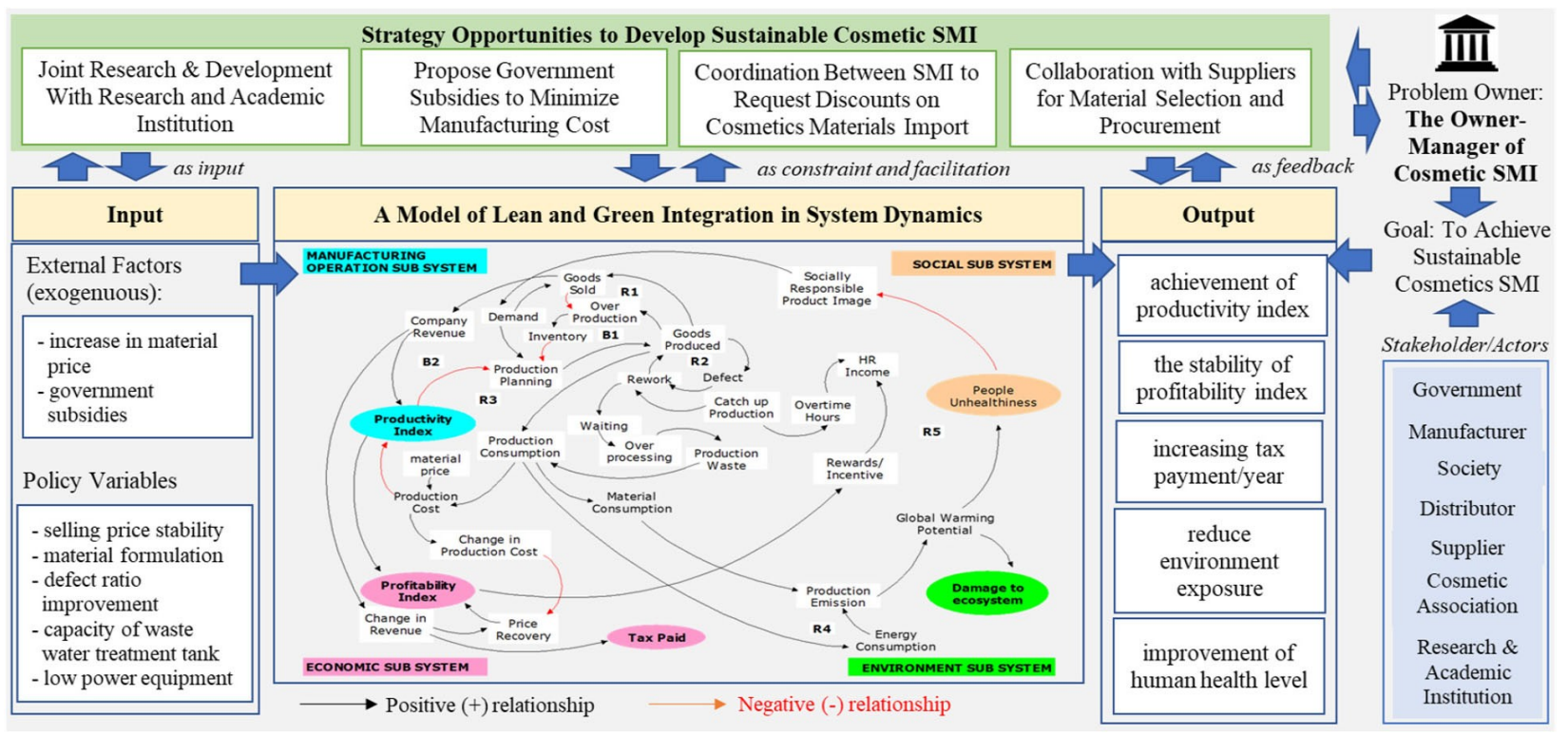

Figure 8. System diagram of the lean and green integration model for achieving sustainable SMI

\section{Conclusions and Future Work}

This study combines literature analysis, multi-actor analysis, system thinking, and field observations to develop a conceptual model for sustainable cosmetics SMI. The system diagram structures a complete and compact picture as the conceptual model. In particular, the researchers explored lean and green variables and their dynamics interconnections, system goals and input-output, barriers, and strategic opportunities. The system diagram determines five output indicators: the productivity index, profitability ratio, tax payments, environmental impact, and human health using the causal relationships between 30 lean and green variables. It identifies three external input factors and five policy variables. This input-process-output relationship was explained via a CLD.

The developed CLD illustrates the growth and under-investment archetype. This pattern shows that cosmetics SMI managers must encourage optimal investment support to establish a sustainable business that leverages resources to improve their current SMI performance. Considering the limitations of SMI's capital, investment support might come from collaboration with other stakeholders. Four alternative strategies were devised to support managers in the system diagram: joining R\&D with research and academic institutions, requesting that government subsidies support improvement activities to minimize production costs, coordinating between SMIs to propose reductions of material import tariffs, and collaborating with suppliers to select alternative materials that contribute to sustainability.

The conceptual model developed herein helps researchers and decision-makers to improve their understanding of the overall dynamic complexity problems using a system thinking approach in integrating lean and green principles for achieving sustainability. They can detect the causal relationships between variables and the behavioral patterns that create better strategies to achieve sustainable SMIs. The variables and their interconnections in the system diagram were identified through the literature review so that all SMIs can apply this research's implications. However, because this work pertains specifically to Indonesia's cosmetics SMI, some challenges might be unique to developing countries. Future research will use this conceptual model in system dynamics modeling and run simulation scenarios over the long term to predict the continuous achievement of sustainable SMIs.

\section{Declaration of Conflicting Interests}

The authors declared no potential conflicts of interest with respect to the research, authorship, and/or publication of this article.

\section{Funding}

The authors received a grant from The University of Indonesia under PUTI Doctoral Program for the research, authorship, and/or publication of this article. 


\section{References}

Abualfaraa, W., Salonitis, K., Al-Ashaab, A., \& Ala'raj, M. (2020). Lean-green manufacturing practices and their link with sustainability: A critical review. Sustainability, 12(3), 981. https://doi.org/10.3390/su12030981

Aguado, S., Alvarez, R., \& Domingo, R. (2013). Model of efficient and sustainable improvements in a lean production system through processes of environmental innovation. Journal of Cleaner Production, 47, 141-148. https://doi.org/10.1016/j.jclepro.2012.11.048

Amrina, U., \& Zagloel, T.Y.M. (2019). The harmonious strategy of lean and green production: Future opportunities to achieve sustainable productivity and quality. IEEE 6th International Conference on Industrial Engineering and Applications (ICIEA). Tokyo, Japan.

Arif, H., Faraz, N.J., \& Atika, D. (2019). Marketing as a government program priority in optimizing the regional superior product. International Conference of Ethics on Business, Economics, and Social Science (ICEBESS 2018). Yogyakarta, Indonesia.

Arnold, R.D., \& Wade, J.P. (2015). A definition of systems thinking: A systems approach. Procedia Computer Science, 44, 669-678. https://doi.org/10.1016/j.procs.2015.03.050

Asian Development Bank. (2014). Asia SME finance Monitor 2014. Asian Development Bank. https://www.adb.org/sites/default/files/publication/173205/asia-sme-finance-monitor2014.pdf

Bai, C., Kusi-Sarpong, S., Badri Ahmadi, H., \& Sarkis, J. (2019). Social sustainable supplier evaluation and selection: A group decision-support approach. International Journal of Production Research, 57(22), 7046-7067. https://doi.org/10.1080/00207543.2019.1574042

Baines, T.S., Brown, S., Benedettini, O., \& Ball, P.D. (2012). Examining green production and its role within the competitive strategy of manufacturers. Journal of Industrial Engineering and Management, 5(1), 53-87.

https://doi.org/10.3926/jiem.405

Balachandran, K., Taticchi, P., Clarke-Sather, A.R., Hutchins, M.J., Zhang, Q., Gershenson, J.K., et al. (2011). Guest editorial. International Journal of Accounting and Information Management, 19(3).

https://doi.org/10.1108/ijaim.2011.36619caa.001

Bergmiller, G.G. (2006). Lean manufacturers transcendence to green manufacturing: Correlating the diffusion of lean and green manufacturing systems. Unpublished doctoral dissertation. University of South Florida.

Braun, W. (2002). The system archetypes. System, 27. http://my2.ewb.ca/site media/static/attachments/group topics grouptopic/86984/systemarchetypes.pdf.pdf

Cherrafi, A., Elfezazi, S., Garza-Reyes, J.A., Benhida, K., \& Mokhlis, A. (2017). Barriers in green lean implementation: A combined systematic literature review and interpretive structural modelling approach. Production Planning and Control, 28(10), 829-842. https://doi.org/10.1080/09537287.2017.1324184

Curran, M.A. (2006). Life-cycle assessment: Principles and practice. Scientific Applications International Corporation. http://people.cs.uchicago.edu/ ftchong/290N-W10/EPAonLCA2006.pdf

Demirbas, D., Holleville, L., \& Bennett, D. (2018). Evaluation and comparison of lean manufacturing practices in Britain and France: A case study of a printing solutions organisation. Journal of Economy Culture and Society, 57, 93-150. https://doi.org/10.26650/JECS422720

Dey, P.K., Yang, G.L., Malesios, C., De D., \& Evangelinos, K. (2019). Performance management of supply chain sustainability in small and medium-sized enterprises using a combined structural equation modelling and data envelopment analysis. Computational Economics, 1-41. https://doi.org/10.1007/s10614-019-09948-1

Eaton, M. (2013). The lean practitioner's handbook. Kogan Page Publishers.

Eniola, A.A., \& Entebang, H. (2016). Financial literacy and SME firm performance. International Journal of Research Studies in Management, 5(1), 31-43. https://doi.org/10.5861/ijrsm.2015.1304 
Gandhi, N.S., Thanki, S.J., \& Thakkar, J.J. (2018). Ranking of drivers for integrated lean-green manufacturing for Indian Manufacturing SMEs. Journal of Cleaner Production, 171, 675-689. https://doi.org/10.1016/j.jclepro.2017.10.041

Grifell-Tatjé, E., \& Lovell, C. A. K. (2014). Productivity, price recovery, capacity constraints and their financial consequences. Journal of Productivity Analysis, 41(1), 3-17. https:/ / doi.org/10.1007/s11123-013-0373-8

Gubrium, J.F., Holstein, J.A., Marvasti, A.B., \& McKinney, K.D. (2012). The SAGE handbook of interview research: The complexity of the craft. SAGE.

Gupta, S.M. (2016). Lean manufacturing, green manufacturing and sustainability. Journal of Japan Industrial Management Association, 67(2E), 102-105. https://doi.org/10.11221/jima.67.102

Gupta, V., Narayanamurthy, G., \& Acharya, P. (2018). Can lean lead to green? Assessment of radial tyre manufacturing processes using system dynamics modelling. Computers and Operations Research, 89, 284-306. https://doi.org/10.1016/j.cor.2017.03.015

Halbe, J., \& Pahl-Wostl, C. (2019). A methodological framework to initiate and design transition governance processes. Sustainability, 11(3), 844. https://doi.org/10.3390/su11030844

Hallam, C., \& Contreras, C. (2016). Integrating lean and green management. Management Decision, 54(9), $2157-2187$. https://doi.org/10.1108/MD-04-2016-0259

Hartanto, B.W., \& Subagyo, S. (2018). Kerangka kerja perencanaan pengembangan produk sebagai peningkatan Daya Saing industri kecil menengah. Jurnal Teknosains, 8(1), 26-38. https://doi.org/10.22146/teknosains.35574

Hermans, L.M., \& Cunningham, S.W. (2013). Actor models for policy analysis. In Thissen, W., \& Walker, W. (Eds.), Public Policy Analysis (185-213). International Series in Operations Research and Management Science. Springer. https://doi.org/10.1007/978-1-4614-4602-6_8

Hidayatno, A., Destyanto, A.R., \& Noor, S.T. (2019). Conceptualizing carbon emissions from energy utilization in Indonesia's industrial sector. Energy Procedia, 156, 139-143. https://doi.org/10.1016/j.egypro.2018.11.118

Hidayatno, A., Rahman, I., \& Muliadi, R. (2012, October 2-4). A system dynamics sustainability model to visualize the interaction between economic, social, and environmental aspects of Jakarta's urban development. International Seminar on Science and Technology Innovation. University Al-Azhar Indonesia, Jakarta.

Hines, P., \& Rich, N. (1997). The seven value stream mapping tools. International Journal of Operations and Production Management, 17(1), 46-64. https://doi.org/10.1108/01443579710157989

Karasan, A., Erdoğan, M., \& Ilbahar, E. (2018). Prioritization of production strategies of A manufacturing plant by using an integrated intuitionistic fuzzy AHP and TOPSIS approach. Journal of Enterprise Information Management, 31(4), 510-528. https://doi.org/10.1108/JEIM-01-2018-0001

Kementerian Perindustrian. (2018). The national cosmetic industry grows 20\%. Kementerian Perindustrian. Rebuplic of Indonesia. http://www.kemenperin.go.id/artikel/18957/Industri-Kosmetik-Nasional-Tumbuh-20

Khayam, M. (2019). Life cycle assessment (LCA) to support the competitiveness of industries and local products at the international level. 4th ILCAN Conference Series on Life Cycle Assessment. Jakarta.

Kim, D.H. (1999). Introduction to systems thinking. Pegasus Communications, Inc.

Kim, D.H., \& Anderson, V. (1998). Systems archetype basics. Pegasus Communications Inc.

Kropsu-Vehkapera, H., \& Isoherranen, V. (2018). Lean approach in knowledge work. Journal of Industrial Engineering and Management, 11(3), 429-444. https://doi.org/10.3926/jiem.2595

Krueger, R.A. (2014). Focus groups: A practical guide for applied research. Sage Publications.

Kull, T.J., Kotlar, J., \& Spring, M. (2018). Small and medium Enterprise research in supply chain management: The case for single-respondent research designs. Journal of Supply Chain Management, 54(1), 23-34.

https://doi.org/10.1111/jscm.12157 
Kumar, S., Dhingra, A., \& Singh, B. (2018). Lean-Kaizen implementation: A roadmap for identifying continuous improvement opportunities in Indian small and medium sized enterprise. Journal of Engineering, Design and Technology, 16(1), 143-160. https://doi.org/10.1108/JEDT-08-2017-0083

Miller, G., Pawloski, J., \& Standrigde, C.R. (2010). A case study of lean, sustainable manufacturing. Journal of Industrial Engineering and Management, 3(1), 11-32. https://doi.org/10.3926/jiem..v3n1.p11-32

Ministry of Environment (2014). Regulation of the Environment Ministry Number 03 of 2014. Ministry of the Environment, Indonesia.

Mittal, V.K., Sindhwani, R., \& Kapur, P.K. (2016). Two-way assessment of barriers to lean-green manufacturing system: Insights from India. International Journal of System Assurance Engineering and Management, 7(4), 400-407. https://doi.org/10.1007/s13198-016-0461-z

Mittal, V.K., Sindhwani, R., Kalsariya, V., Salroo, F., Sangwan, K.S., \& Singh, P.L. (2017). Adoption of integrated lean-green-agile strategies for modern manufacturing systems. Procedia CIRP, 61, 463-468.

https://doi.org/10.1016/j.procir.2016.11.189

Morgan, D.L. (2012). Focus groups and social interaction. In Gubrium, J.F., Holstein, J.A., Marvasti, A.B., \& McKinney, K.D. (Eds.), The SAGE handbook of interview research: The complexity of the craft (2nd ed.). SAGE. https://dx.doi.org/10.4135/9781452218403.n11

Muñoz-Pascual, L., Curado, C., \& Galende, J. (2019). The triple bottom line on sustainable product innovation performance in SMEs: A mixed methods approach. Sustainability, 11(6), 1689. https://doi.org/10.3390/su11061689

Nakano, M., \& Kojima, F. (2017). Special issue on green and lean production. International Journal of Automation Technology, 11(4), 541-541. https://doi.org/10.20965/ijat.2017.p0541

Panizzolo, R., Garengo, P., Sharma, M.K., \& Gore, A. (2012). Lean manufacturing in developing countries: Evidence from Indian SMEs. Production Planning and Control, 23(10-11), 769-788.

https://doi.org/10.1080/09537287.2011.642155

Panwar, A., Jain, R., \& Rathore, A.P.S. (2016). Obstacles in lean implementation in developing countries - some cases from the process Sector of India. International Journal of Lean Enterprise Research, 2(1), 26-45. https://doi.org/10.1504/IJLER.2016.078228

Prusty, S.K., Mohapatra, P.K.J., \& Mukherjee, C.K. (2014). System archetype to understand unintended behavior in Indian shrimp industry and to aid in strategy development. Systemic Practice and Action Research, 27(4), 397-416. https://doi.org/10.1007/s11213-013-9288-6

Pusat Komunikasi Publik Kementerian Perindustrian. (2015). The Master Plan of National Industrial Development For 2015-2035. Pusat Komunikasi Publik Kementerian Perindustrian. Jakarta.

Ramos-Quintana, F., Sotelo-Nava, H., Saldarriaga-Noreña, H., \& Tovar-Sánchez, E. (2019). Assessing the environmental quality resulting from damages to human-nature interactions caused by population increase: A systems thinking approach. Sustainability, 11(7), 11. https://doi.org/10.3390/su11071957

Reich-Weiser, C., Simon, R., Fleschutz, T., Yuan, C., Vijayaraghavan, A., \& Onsrud, H. (2013). Metrics for green manufacturing. In Dornfield, D.A. (Ed.), Green manufacturing (49-81). Springer. https://doi.org/10.1007/978-1-44196016-0_3

Reis, L.V., Kipper, L.M., Giraldo Velásquez, F.D., Hofmann, N., Frozza, R., Ocampo, S.A., et al. (2018). A model for lean and green integration and monitoring for the coffee sector. Computers and Electronics in Agriculture, 150, 62-73. https://doi.org/10.1016/j.compag.2018.03.034

Resta, B., Gaiardelli, P., Pinto, R., \& Dotti, S. (2016). Enhancing environmental management in the textile sector: An organisational-life cycle assessment approach. Journal of Cleaner Production, 135, 620-632.

https://doi.org/10.1016/j.jclepro.2016.06.135 
Schwab, L., Gold, S., Kunz, N., \& Reiner, G. (2017). Sustainable business growth: Exploring operations decisionmaking. Journal of Global Responsibility, 8(1), 83-95. https://doi.org/10.1108/JGR-11-2016-0031

Singh, R.K., Modgil, S., \& Tiwari, A.A. (2019). Identification and evaluation of determinants of sustainable manufacturing: A case of Indian cement manufacturing. Measuring Business Excellence, 23(1), 24-40. https://doi.org/10.1108/MBE-08-2018-0056

Sterman, J. (2010). Business dynamics. McGraw-Hill.

Su, T., Ji, J., Huang, Q., \& Chen, L. (2019). Materialism, social stratification, and ethics: Evidence from SME owners in China. International Journal of Entrepreneurial Behavior and Research, 25(3), 499-517.

https://doi.org/10.1108/IJEBR-11-2017-0435

Thanki, S., Govindan, K., \& Thakkar, J. (2016). An investigation on lean-green implementation practices in Indian SMEs using analytical hierarchy process (AHP) approach. Journal of Cleaner Production, 135, 284-298. https://doi.org/10.1016/j.jclepro.2016.06.105

The Medicine and Food Supervisory Agency. (2019). Regulation of the medicine and food supervisory agency Number 25 of 2019. Minister of Health, Indonesia.

Van Mai, T., \& To, P.X. (2015). A systems thinking approach for achieving A better understanding of swidden cultivation in Vietnam. Human Ecology, 43(1), 169-178. https://doi.org/10.1007/s10745-015-9730-8

Vera, P., Nikulin, C., Lopez-Campos, M., \& Gonzalez Ramirez, R.G.G.G. (2019). Prospective study using archetypes and system dynamics. Academia Revista Latinoamericana de Administración, 32(2), 181-202. https://doi.org/10.1108/ARLA-05-2017-0151

Wagner, M., Van Phu, N., Azomahou, T., \& Wehrmeyer, W. (2002). The relationship between the environmental and economic performance of firms: An empirical analysis of the European paper industry. Corporate Social Responsibility and Environmental Management, 9(3), 133-146. https://doi.org/10.1002/csr.22

Wang, Z., Subramanian, N., Gunasekaran, A., Abdulrahman, M.D., \& Liu, C. (2015) Composite sustainable manufacturing practice and performance framework: Chinese auto-parts suppliers' perspective. International Journal of Production Economics, 170, 219-233. https://doi.org/10.1016/j.ijpe.2015.09.035

Wu, P., \& Low, S.P. (2012). Lean management and low carbon emissions in precast concrete factories in Singapore. Journal of Architectural Engineering, 18(2), 176-186. https://doi.org/10.1061/(ASCE)AE.1943-5568.0000053

Yacob, P., Wong, L.S., \& Khor, S.C. (2019). An empirical investigation of green initiatives and environmental sustainability for manufacturing SMEs. Journal of Manufacturing Technology Management, 30(1), 2-25. https://doi.org/10.1108/JMTM-08-2017-0153

Zhou, J., \& Liu, Y. (2015). The method and index of sustainability assessment of infrastructure projects based on system dynamics in China. Journal of Industrial Engineering and Management, 8(3), 1002-1019.

https://doi.org/10.3926/jiem.1496

Journal of Industrial Engineering and Management, 2021 (www.jiem.org)

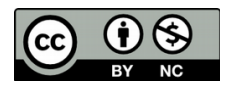

Article's contents are provided on an Attribution-Non Commercial 4.0 Creative commons International License. Readers are allowed to copy, distribute and communicate article's contents, provided the author's and Journal of Industrial Engineering and Management's names are included. It must not be used for commercial purposes. To see the complete license contents, please visit https://creativecommons.org/licenses/by-nc/4.0/. 